\title{
1. Introduction: establishing new frontiers for European entrepreneurship research
}

\section{Ulla Hytti, Robert Blackburn and Silke Tegtmeier}

\section{INTRODUCTION}

The Frontiers in European Entrepreneurship Research series aims to contribute to and extend discussions within entrepreneurship research with the idea of consolidating, questioning and testing conventional wisdom and knowledge. In addition, the goal is to create room for new ideas to help the entrepreneurship research field to evolve into new directions. Finally, the series allows knowledge transfer from previously insular national research communities to a burgeoning wider international entrepreneurship research community (Welter and Lasch, 2008).

In past years, research reviews have been conducted to make sense and highlight what is distinctive about European entrepreneurship research, compared with other regional approaches and specifically in the US (for example, a special issue edited by Welter and Lasch in 2008). In this introduction our aim - both through the chapters included in this volume and by revisiting some of the earlier volumes - is to take stock and elaborate on the possible future directions for European entrepreneurship research. We acknowledge this is an ambitious task and that we are not able to offer a pre-emptive review, or a list of suggestions, but merely act as a starting point for future activities.

In this introductory chapter we will first summarize the chapters in this volume. Then, we discuss the key features of European entrepreneurship research as we understand them, based on existing reviews, as well as what can be seen through this series. The key features are: contextual embeddedness, methodological diversity and distinctive clusters that, in combination, have resulted in versatile contributions that characterize the European entrepreneurship research field. Finally, we suggest avenues for future contributions that we would like to see from the research community and, 
ultimately, published in upcoming volumes in the Frontiers in European Entrepreneurship Research series.

\section{INTRODUCING THE CHAPTERS}

Jones et al. (Chapter 2) take stock on research on migrant entrepreneurship and develop suggestions for future directions. First, they point to the need for comparative studies that would enable understanding how the institutions and policies impact on migrant entrepreneurship. They also highlight that the celebratory discourses depicting the single, heroic migrant entrepreneur (Ogbor, 2000) need to be balanced by deeper understanding of racism and social exclusion. In addition, they envision that migrant entrepreneurship should benefit from more in-depth analyses of gender and generate understanding from gendered arrangements in the household and in the firm. Finally, the authors propose a way forward by focusing on the non-economic, social outcomes from migrant entrepreneurship. Jones et al. underline that the mixed embeddedness theory 'has brought the impact of structures back to the analysis of migrant entrepreneurship, and their interplay with personal networks'.

It is therefore appropriate that Aaltonen and Akola, in Chapter 3, apply a mixed embeddedness framework to investigate, empirically, the role of trust and bridging social capital in immigrant business owners' start-up processes in Finland. The authors argue for the particular case of the Finnish context to investigate the topic since significant immigration is a relatively new phenomenon in Finland. Thus, in contrast to many other contexts, the role of bridging social capital and trust building between immigrant entrepreneurs and the surrounding society are, arguably, more immediate in Finland. Through a qualitative methodology and presenting short vignettes - stories - the study analyses the development of trust, or otherwise, relationships between business owners and their clientele, the entrepreneurship community, authorities and employees. Both occasions of trusting and distrusting were recognized. The findings also reveal the overlapping and interdependent dimensions of social capital. Personal trust between the entrepreneur and clientele becomes important when lacking collective or institutional trust. Shared codes and language strengthen the trust between actors. Trust building can be viewed as a process but it is far from linear. Thus, time needed for trust building may become somewhat a surprise for the immigrant entrepreneurs.

A novel stance is taken by Axelsson, Höglund and Mårtensson in Chapter 4 to contextualize entrepreneurship in a wider context of political and programmatic discourse. The authors rely on a discourse approach, 
drawing upon governmentality and through the concepts of programme and technology to investigate the interpretations of entrepreneurship in a school setting. In particular, they analyse how the strategy for entrepreneurship education (programme) is made operable in practice by a competence development initiative (technology). Governmentality is understood ' . . as a method of governing that encourages action of the self, by the self, rather than through formal institutions' (Axelsson et al., Chapter 4) and '. . . the concept of technology refers to a particular method to analyzing the activity of governing' (ibid.). The findings highlight shifts in time: schools initially privileged the entrepreneurship discourse but moved gradually towards the enterprising discourse. Later, a new entrepreneurial-approach discourse emerged. The authors suggest that this approach develops the initiative from isolated initiative within the school to one encompassing the whole school and the entire educational system. It is seen as natural and positive for everyone, both accessible and necessary to all pupils and teachers. The authors highlight how the schools seem to be stretching and surpassing the initial ideas of the programme. Hence, they can be seen to become entrepreneurial in themselves, making the programme to better fit their own ideas and to avoid working with entrepreneurship in the narrow economic understanding. Axelsson et al. also critically reflect on the possible unintended consequences of the new 'entrepreneurial approach', and identify three sources of potential tensions: between political and societal needs and the freedom of the individual, between entrepreneurship as a tool for democracy and exclusion, and between inclusion and norms of entrepreneurship. The authors suggest that widening the discourse from entrepreneurship, in the economic sense, to the entrepreneurial approach may produce unwanted outcomes: the enterprising self as someone mastering their own faith and producing good for society evokes the core of the economic and market-oriented neo-liberalistic ideal of entrepreneurship.

In Chapter 5, Pospíšilová investigates co-preneurship from a family embeddedness perspective with a particular emphasis on its gendered nature. Co-preneurs are defined as partners who share their responsibilities both in business and family spheres. In the study, the analysis focuses on discourses about the division of tasks at home and work. By studying copreneurs in the specific context of Slovakia, the author also wishes to shed light on the social aspects of entrepreneurship in post-Communist societies and to highlight how the Communist past and present are reflected in the norms, values and attitudes. The research is based on in-depth interviews conducted with each of the partners separately, totalling 21 interviews (one potential participant declined to be interviewed). In the analysis, the focus was directed on identifying cultural repertoires for talking about roles in work and home spheres. The author applied the analytical steps suggested 
by Gioia et al. (2012) to identify patterns in arguments supporting a certain arrangement of division of work. It also aimed at identifying the combination of different repertoires and potential conflicts. The analysis produced five different repertoires: traditional, function-based, responsibility, collective and competence-based repertoires. The traditional repertoire emphasized the 'natural' division of women's care-taker and men's breadwinner roles. Here, also, the contributions of the partners were valued differently, often undermining those of women. In the competence-based repertoire the division of tasks is argumented based on individual abilities, will and enthusiasm. The findings highlight that these preferences are also gendered: women expressing an interest for the tasks at home was applied to explain men's lower participation at home. The functional repertoire was based on formal functions in the business, whilst the responsibility repertoire emphasized a strong sense of responsibility for the business. In the collective repertoire the enterprise is understood as a collective that necessitates everyone's contribution. Interestingly this repertoire was mainly linked to the business sphere, while the domestic sphere was related to the traditional repertoire. The analysis also highlights how the combination of some repertoires can lead into conflicts.

Cesaroni and Sentuti in Chapter 6 contribute to the research on gender and family business by investigating how daughters' career ambitions and expectations influence their actual role in the family business and if this role is aligned with their goals. They highlight that previous research addresses daughters' motivations to join and the different roles available in the family business, as well as the conditions that facilitate or hinder the daughters' ability to take over the family business. They suggest a gap in understanding the relationship between daughters' goals with the actual roles they achieve in the family business. Their study is based on a qualitative, multiple case study involving interviews with the daughters and other family members (where possible) as well as secondary data from business documents and media. The research materials were analysed to identify daughters' professional expectations before entering the family business. This information was cross-checked with their actual role in the family business. This led to a second phase in the analysis, in order to make sense of what led some participants to accept a role that is inconsistent with their original goals. The analysis produced a typology of four profiles: leaders by choice, compelled leaders, managers by choice and compelled managers. Leaders by choice are daughters who are able to take over the family business and fulfil their goals. The authors note that in these family businesses there were no sons, and daughters taking over the firm was thus considered natural. Compelled leaders are daughters who take over the family business not because of their own desire but mainly because 
of a sense of responsibility towards their family and parents. Managers by choice represent daughters who work in the family business in limited managerial roles and have left the leadership to their siblings. Compelled managers are daughters who had a goal of taking over the firm but were forced to settle for a minor role. They settle with this role as they feel that they cannot question the role of their brothers in the leadership of the firm and that they feel strongly attached to the family and family business.

Yar Hamidi, in Chapter 7, focuses on a neglected area of board leadership in small and medium-sized enterprises (SMEs) by investigating the effects of chairperson leadership, knowledge and experience on firms' abilities to build dynamic capabilities. As opposed to many studies in this area that rely on archival or secondary data, the study applies first-hand survey data. In contrast to existing studies considering boards from an external perspective, this research assumes the agency theory by using the resourcedependency perspective to investigate the effect of board leadership. The data set is derived from the Norwegian value-creating board surveys collected in 2005 and 2006 and the final sample consists of 315 cases of SMEs with boards of at least two members. Multiple linear regressions were conducted to develop three models. The findings offer support for two of the hypotheses, indicating that there is a strong positive association between the chairperson's leadership efficacy and the formation of dynamic capabilities (H1) and between the chairperson's firm-specific knowledge and the formation of dynamic capabilities (H2). However, the third hypothesis is not supported since findings indicate a moderate reverse relationship between chairperson's industry experience and the formation of dynamic capabilities in SMEs. The author suggests that this may indicate that extensive industry experience may lead to conformity of the industry rules and norms that are taken for granted by the chair, and therefore less likely to aim at strategic change.

In Chapter 8, Lepistö, Aaltonen and Hytti investigate how strategy is constructed in a dialogue between independent consultants in a partnership. The authors argue for the need to understand strategies in a network context comprising different stakeholders, and not only in connection to a single firm. They also argue the need for more empirical research in co-creation and strategy in a micro firm context. Current research has mainly been undertaken in the marketing context, investigating the co-creation between the firm and its customers but neglected in the area of strategy work in micro and small firms. The analysis relies on the strategy-as-practice approach, which views strategy as something people do with people from inside and outside an organization. The interest lies in practices comprising understandings, procedures and engagements. The chapter utilizes a case methodology, where the case is the strategy dialogue 
in workshops consisting of the partnering consultants in two different micro firms. Research materials consist of observational, recorded and transcribed materials from two workshops. The findings highlight five different practices of co-strategizing: dialoguing 1) about the customer; 2) who we are and what we do; 3) use of experience and knowledge in customer co-operation; 4) required steps in the future; 5) need for a customer perspective. Hence, the chapter suggests that decisions about the customer are not only important in the start-up phase, but a dialogue about the main customer is a relevant ongoing practice in co-strategizing. Varied expertise and experience of the partners participating in the strategizing is regarded as both a challenge and opportunity: it opens up new commercial avenues but the different expectations need to be managed and reconciled. The strategy is viewed as an outcome of social construction involving the multiple partners, and as an iterative and ongoing process. Finally, the chapter highlights the opportunities of dialogue and workshops as tools for micro firms in strategy development, working together with the various stakeholders.

Chapter 9 by Rannikko, Tornikoski, Isaksson, Löfsten and Rydehell focuses on firm growth in order to answer two research questions: 1) what happens to new technology-based firms (NTBFs) in their first seven years; 2 ) how the surviving firms grow when different measures of growth are applied. The chapter suggests that much existing growth research is on larger firms and thus leaves out its links with entrepreneurial activity. Second, the chapter highlights the persistent confusion around growth measures and argues for the need for multiple indicators, to allow for comparisons between studies, enabling knowledge accumulation in this area. The authors aim to add new knowledge to the field by adopting a cohort approach, allowing a focus on new and small firms and to study why and when firms exit the population and which firms remain in it. They adopt various different measures of growth in studying NTBFs. Methodologically the chapter is based on the entire population of NTBFs founded in Sweden in $2006(\mathrm{~N}=1,525)$. The findings suggest first that surprisingly many firms from the 2006 cohort still operate in the end of year 2014 (1,072 firms equalling to a survival rate of 70 per cent). Second, independent on the growth measure applied, only a small minority of firms represent high-growth firms (between 0,6-3 per cent of all firms). The number of high-growth firms is highly dependent on the definition. The findings corroborate the idea that few NTBFs account for the main economic benefits in terms of sales and employment growth. However, job generation exceeds job destruction for every year in the 2006 cohort. Sales and employment growth among high-growth firms were correlated, which counters some existing research. Finally, the authors suggest the potential 
usefulness of the 'kink-point approach' to capture much of the growth excluded in other measures.

\section{TAKING STOCK OF EUROPEAN ENTREPRENEURSHIP RESEARCH}

\section{Contextual Embeddedness in European Entrepreneurship Research}

Welter and Lasch (2008) highlighted that the focus on European entrepreneurship research underlines the importance of grounding research in its national context. This idea is further corroborated in a recent book (Welter et al., 2016). Schmude et al. (2008) speculated that the trend of the younger generation of researchers towards publishing in international arenas might level out this distinctiveness. However, in particular after Welter's (2011) article, our attention to context has been raised to new levels and it has become increasingly difficult to theorize about entrepreneurship without paying attention to the context. The implications of the need for contextual research was something acknowledged also by Blackburn et al. (2015a) suggesting that, rather than understanding the role of context to be linked to the need to generate research from new, perhaps even exotic geographic regions, there is a need to generate new understandings on how contexts, and the continuous changes in the environments, are also giving birth to new forms of entrepreneurship that need to be contextually investigated.

Through the chapters in this volume, it is clear that the European entrepreneurship scholars are sensitive to contextualizing their research. An excellent illustration is possible through migrant entrepreneurship and the various forms within. The institutional differences and, for example, the very divergent historical roots in migration within the European Union, offer a great environment for researching how diverse institutions and policies impact on migrant entrepreneurship (Jones et al., Chapter 2). By narrowing the focus to the Nordic countries, it is also possible to see that the two neighbouring countries of Sweden and Finland share very different historical trajectories when it comes to the immigration policies and therefore the number of immigrants to these countries over the years. Aaltonen and Akola (Chapter 3) pick up on this matter by suggesting that, due to the relatively recent migration to Finland, it is interesting to study the role of trust and social capital between the immigrant entrepreneurs and the surrounding environment in this context. Furthermore, certain national contexts with certain practices allow the study of certain topics. For example, Yar Hamidi (Chapter 7) suggests that research on SME 
boards makes sense in Norway since the Norwegian SME boards are traditionally active. Indeed, one can easily envision how research into SME boards might be completely hypothetical in many country contexts as they do not exist or exist in paper only. Yar Hamidi also acknowledges the differences and similarities in the Norwegian corporate governance system to establish the boundaries and limitations of how the results from the study may be applicable to other contexts. Similarly, Rannikko et al. (Chapter 9) ground their decision to study growth of new technology-based firms in the Swedish context, since Sweden is known for its advanced registration system, enabling their ambitious cohort study of following all new technology-based firms established in the year 2006, with the study carried out between 2007 and 2013.

While contributions from the UK-based researchers into entrepreneurship are well known (for example, Blackburn and Smallbone, 2008) and exemplified by Shaw et al. (2017), European entrepreneurship research can advance by developing research into the various new and emerging contexts. As Welter et al. (2016) suggest, much of our context thinking stems from the 'other contexts'. For example Pospíšilová (Chapter 5) investigates co-preneurship in the Slovakian contexts in order to highlight how the Communist past and also present are reflected in the values, norms and attitudes in the cultural repertoires when co-preneurs talk about their roles in work and home spheres. Context was also present in the study through the family embeddedness perspective. Thus, Pospísilová contributes to the emerging awareness within European entrepreneurship research that the traditional focus on the individual, or the firm, needs to move towards a much greater appreciation of the need to understand the role of the family and household in which the entrepreneur is embedded and from which the firm emerges (Alsos et al., 2014).

Pittaway and Cope (2007) noted in their review article that entrepreneurship education research has been effective in examining different forms of pedagogy and their value within entrepreneurship education, but there also seems to be a need for more contextual research in entrepreneurship education. In other words, there needs to be a recognition that context influences what is meant by 'entrepreneurship' or 'enterprise education' within the context studied. Axelsson et al. (Chapter 4) contribute to addressing this omission by contextualizing entrepreneurship in a wider context of political and programmatic discourses in a school context. The authors suggest that broadening the scope and meaning of entrepreneurship from the narrow economic understanding may evoke the core of the neo-liberalistic ideal of entrepreneurship. 


\section{Methodological Diversity}

Previous reviews of European entrepreneurship research have been uniform in that its distinctiveness lies in the openness to methodological diversity, both when Europe is understood as a whole (Welter and Lasch, 2008), or in specific country contexts (Hjorth, 2008; Blackburn and Smallbone, 2008; Schmude et al. 2008). This openness to diversity is also reflected in the Frontiers in European Entrepreneurship Research series (Hytti et al., 2016; Blackburn et al., 2014; Blackburn et al., 2015b; Welter et al., 2012; Welter et al., 2013). The series is also indicative of the strong European tradition of qualitative research. A majority of chapters in the series use various qualitative methodologies (from different types of case study approaches to discourse analyses, ethnographies to name a few), to apply different research materials (such as interviews, media texts, diaries, secondary sources and so forth). However, a significant amount of quantitative research, relying on primary survey or secondary data, or registry-based data, is also evident in the series. This methodological richness, with an emphasis on qualitative perspectives, is also clear in this volume with research contributions spanning conceptual reviews, to (multiple) case studies involving interview data, as well as additional sources to discourse, analyses of policy texts adopting both realist and interpretivist perspectives. Yet, the volume also includes chapters based on survey- and registry-based data.

European research has also a tradition of questioning taken-for-granted assumptions of entrepreneurship and escaping overemphasizing the so dominant individual agency approach in entrepreneurship research. But this also links to the appreciation of the context (Welter et al., 2016) and a number of points can be made here.

First, entrepreneurship research has contributed to adding and extending these 'celebratory discourses' whether in the form of 'uncritical admiration of the small firm' (Jones et al., Chapter 2), or advocating the single heroic entrepreneur and their agency in entrepreneurship (Ogbor, 2000). In this volume, Jones et al. warn against this when investigating migrant entrepreneurship. Cesaroni and Sentuti (Chapter 6) participate in this discussion by understanding that the individual agency may be bounded by the family (business), and thus it is not sufficient to understand, for example, daughters' access to family business leadership solely from the perspective of their willingness but in connection with their actual role achieved. Lepistö et al. (Chapter 8), for their part, suggest that the individual micro firm as an omnipotent agentic power in strategizing may be an illusion and emphasize the need to understand the strategies in a network context. On the other hand, Yar Hamidi (Chapter 7) noted a lack of focus on the 
individual in research on company boards that has relied on archival data and assumed boards 'as collectives' to be investigated from the external perspective. Therefore, the study focuses on the chairperson of the board.

Second, much entrepreneurship research has an underpinning assumption of entrepreneurship as a predominantly positive phenomenon, despite some evidence of its dark side and limitations. One example is in the entrepreneurship education research that either explicitly or implicitly seems to be advocating that more entrepreneurship education is better and where axiological questions are largely missing: do we want to? should we? and how should we do it? (Kyrö, 2015). Axelsson et al. (Chapter 4) embrace this view and discuss how, by trying to move away from the neo-liberal ideal of entrepreneurship and broadening the scope, we are actually evoking the core of the economic and market-oriented ideal.

Third, Rannikko et al. (Chapter 9) highlight that, even in areas with an important body of research and one of the established core fields in entrepreneurship research, as with firm growth, research may not have actually been able to address the actual entrepreneurial activity because of methodological challenges. Thus, it is necessary at times to challenge the type of research approaches that we employ in order to actually move towards the direction we wish to go.

\section{Distinctive Clusters of European Entrepreneurship Research}

In light of the above discussion - contextualized research and methodological diversity together with heterogeneity of the field in terms of theoretical approaches and paradigmatic lenses - it is not surprising that the Frontiers of European Entrepreneurship Research series continues as a playground for contributions that are embedded within various 'academic disciplines rather than the generation of a new all-embracing small business or entrepreneurship paradigm' (Blackburn and Smallbone, 2008, p.282). Some 20 years ago 'the lack of theory in entrepreneurship' was often identified as a problem in international, particularly US-based, journals (see for example Bull and Willard, 1993; Ripsas, 1998) with the implication (and sometimes exhortation) that entrepreneurship research should strive at it. Perhaps the call for this uniform direction was less prevalent in Europe. Rather the assessment of Blackburn and Smallbone (2008) in terms of the entrepreneurship research in the UK consisting of a number of distinctive clusters is applicable to Europe as a whole. This can be seen by revisiting the Frontiers in European Entrepreneurship Research series in the previous five years (Welter et al., 2012; Welter et al., 2013; Blackburn et al., 2014; Blackburn et al., 2015b; Hytti et al., 2016).

The various facets of venture growth have been discussed in many 
volumes. The contributions have ranged from looking at the role of the entrepreneur (O'Gorman, 2012) to studying the effects of the local environment (Sleutjes et al., 2012) on growth. O'Gorman's (2012) findings suggest that growth may be intrinsic to the founder's decision to found the firm. In addition, the study highlighted the need for longitudinal research in growth studies. Sleutjes et al. (2012) demonstrate how neighbourhood liveliness and cohesiveness are related to firm success and growth. García-Villaverde et al. (2012) on their part aim to understand the relationship between pioneering and new product performance and suggest that pioneering may be a risky strategy for firms. Courault et al. (2014) added a new twist to researching growth and investigated the failure of high-growth SMEs. Their findings suggest that failures resulted due to challenges in addressing pace of development and inadequate profitability (and not from poor market opportunities).

Another important cluster of research links to the resources and capabilities. A review article investigating how knowledge is understood in entrepreneurship research, and advocating a need for theory to explain the knowledge construction process of entrepreneurs, is published by Campos and Hormiga in 2012. Brand et al. (2012) challenge the assumptions with regard to codified knowledge for franchising companies and suggest that franchisees also need local knowledge. Wright (2012) discusses how economic conditions may offer opportunities for entrepreneurial mobility but they also pose challenges for assembling the resources required for firm creation and development. Grande (2013) studies resources and capabilities required for successful entrepreneurship in agriculture, and Yavuz et al. (2016) investigate how resources - and resource flexibility - can impact on internationalization in start-ups. Salamonsen (2016) addresses alliances between large and small firms and suggests that the non-spatial proximity (personal relationships, shared experience and industry, mutual dependence) can help small firms succeed in collaborating with large firms. Guerrero and Peña-Legazkue (2014) investigated the relationship between human capital and firm creation, and Gabrielsson et al. (2014) examined how innovation speed in technology start-ups is influenced by technologies and markets, and contribute to the knowledge of how different types of uncertainty influence the commercialization of technologies. Finance is identified as an important resource, and the use of financial bootstrapping on venture growth was examined by Laveren et al. (2012). Crowdfunding and, in particular, equity crowdfunding as a new source of finance for new ventures was studied by Huynh (2016). While funding is important, research by Nevalainen and Eriksson (2016) highlighted the role of nonfinancial contributions from business angels and the dynamic nature of these contributions. 
Close connection between entrepreneurship and $S M E$ research to policy making was identified as something distinctive to the UK research (Blackburn and Smallbone, 2008). In a UK-based study, Kitching et al. (2013) investigated the administrative burdens in relation to small firms and whether regulations influence - and if so how they influence - smallbusiness performance. But interest into policies is not limited to the UK. Örge (2013) analysed how power relations impact upon entrepreneurship policies, and he demonstrates how policy discourses contribute to legitimizing certain specific policies in Turkey. In addition, he demonstrates how by describing the target as weak the policy maker's heroic role can be emphasized. Bertoni et al. (2013) investigated the effectiveness of publicventure financing in supporting young high-tech companies in Italy.

Another distinctive cluster is related to the academic entrepreneurship and role of universities in knowledge transfer. Bianchi et al. (2013) studied the role of technology transfer offices for entrepreneurial universities, and Horner and Giordano (2016) discuss how university-industry partnerships can enhance open innovation at the regional level, and suggest that the universities can have an impact on the region beyond the formal knowledge transfer. But research in this area is also done at the firm and individual level: openness and innovativeness within science-based firms was investigated by Rasmussen and Clausen (2012), and differing characteristics of technology entrepreneurs to networking were studied by Billström et al. (2014); Karhunen and Olimpieva (2016) investigated role identities of science-based entrepreneurs and suggested an emergence of a hybrid role identity.

The development of entrepreneurial intentions in particular in the educational context is also an established area of study. Mauer et al. (2013) studied the factors that play a role in the formation of self-efficacy and entrepreneurial intentions of students, and measured all main antecedents to self-efficacy. Guerrero and Urbano (2015) on their part confirmed that the university and the social context plays a role: a favourable perception of the university environment and the social environment, mediated by cognitive factors, had a positive effect on entrepreneurial intentions. Finally, Varamäki et al. (2016) examined the realization of entrepreneurial intentions of students in entrepreneurial behaviour after graduation. They confirmed that intentions measured during education explain behaviour. It may be considered somewhat surprising that entrepreneurship education research beyond the study of intentions is missing from this series, given that it is a field where European entrepreneurship researchers have been very active. This can be seen in the number of highly cited publications from different authors (such as Gibb, 1993; Gibb, 2002; Pittaway and Cope, 2007; Fayolle et al., 2006; Hytti and O'Gorman, 2004), in edited 
books (for example, Fayolle, 2007; Fayolle and Kyrö, 2008) and the inauguration of the new European research conference (3E) in entrepreneurship education since 2013.

In recent years, a more focused emphasis on gender issues in entrepreneurship, understood both as focusing female entrepreneurship and also gendering as a process, can be identified in the series. Marlow (2015) provided a critique of entrepreneurship research projecting women entrepreneurs as underperforming. Tegtmeier and Mitra (2015) demonstrated that human capital accumulation has an impact on entrepreneurial self-efficacy of female entrepreneurs. Thus, women's entrepreneurship, for example, is influenced by education but also the quality of their careers. Gögüss et al. (2015) investigated the gendered consequences of entrepreneurship competitions and suggested that, instead of empowering women, the competitions may in fact produce the contrary results by reaffirming the dominant male and masculine entrepreneurship ideals. Byrne and Fattoum (2015) investigated gender in family business successions and illustrate the gendered nature of successor selection beyond the binary categorization of women and men.

While the bulk of research in the area of small business research focuses on entrepreneurs at the individual level, it is possible to find two exceptions from this Frontiers series in the past five years. First, Schlosser (2014) investigated profiles of SME owners and employees and their differences in relation to firm age and entrepreneurial orientation. The study suggested that SME owners' preference to recruit similar or different employees is connected to the firm. Second, Aaltonen and Hytti (2015) investigated practices hindering employee innovative behaviour in SMEs and suggested two sets of practices, first dealing with the firm size and second with the management style of the chief executive officer (CEO).

By aiming at carving a broader playing field for entrepreneurship, entrepreneurship research has witnessed the emergence of different forms of entrepreneurship. Corporate entrepreneurship has been investigated in a large-firm context (Belousova and Gailly, 2012), and Heinonen et al. (2013) on their behalf shifted attention to public health care and intrapreneurship, and identified five boundaries for intrapreneurship in public health-care organizations. Bosma et al. (2014) analysed the prevalence of intrapreneurship across 11 countries, establishing that intrapreneurs were more prevalent in high-income economies. Social entrepreneurship is a fast-growing topic internationally, and Aggestam (2014) and Johannisson et al. (2016) have contributed to this topic. Aggestam (2014) focused on the individual characteristics of social entrepreneurs and their contribution to extreme poverty, and demonstrated that the significance of human activity can shape positive outcomes. In their contribution, Johannisson et 
al. (2016) investigated practices of social entrepreneurship to identify their structural and processual features. The chapter highlighted the importance of collective effort and local adaption but also financial resources for social enterprises. Institutional entrepreneurship can be seen a paradox, as explained by Hermes and Mainela (2015), as individuals are needed to change the institutions they are part of. Zahra et al. (2013) suggested that understanding the value of entrepreneurship necessitates a better understanding of counterproductive entrepreneurship.

Finally, compared with the international interest in entrepreneurial opportunity research (Ardichvili et al., 2003, Léger-Jarniou and Tegtmeier, 2017) and entrepreneurial orientation (Lumpkin and Dess, 1996, 2001; Wiklund and Shepherd, 2005), it is surprising that only a few chapters in the past years have contributed to research in these two areas. Hurmerinta and PaavilainenMäntymäki (2013) study how entrepreneurs identify, evaluate and capitalize on opportunities by investigating diaries. They suggest that the opportunity process is bounded by context and time. Randerson et al. (2014) addressed the relationship between entrepreneurial orientation and firm performance. Their goal is to understand the links between the personality of the manager, the characteristics of the organization and the environment and organizational performance. Hence, we might offer a suggestion that the European entrepreneurship research is more interested in the 'other' topics than in the mainstream, and that even when these mainstream topics are of interest, the angle is very much focused on understanding the contexts.

\section{OUTLOOK FOR FUTURE EUROPEAN ENTREPRENEURSHIP RESEARCH}

The emphasis in this chapter has been to give more room for recognizing differences in entrepreneurship research and therefore being sensitive to context. This implies that there is more room than ever for European entrepreneurship research to give priority to the local and particular (Hjorth, 2008), and thus enable research questions that are resonant with this focus - and have gone unnoticed, ignored or bypassed - to be addressed. Hence, we align with Welter et al.'s (2016) suggestion that future research should endeavour to understand the differences but also similarities, and possibly even the configurations of contexts.

Second, a focus on contexts and for questioning the taken-for-granted seems to point towards support for critical entrepreneurship research approaches but hopefully not in isolation/separated from the mainstream. To advance our thinking and our research, it is necessary to assume a critical stance and to invite critical analyses of entrepreneurship, but in ways 
that are not satisfied with the negative critique of entrepreneurship but ones that aim at (collective) reflection on when, what kind and if entrepreneurship is appropriate (Alvesson and Spicer, 2012). Thus, for example, the suggestion put forward by Zahra et al. (2013) to increase our understanding of counterproductive entrepreneurship deserves attention. This means opening up our analyses to the potential unwanted consequences of entrepreneurship policy making (Örge, 2013) or entrepreneurship education (Axelsson et al., Chapter 4). It is with these thoughts that we conclude by seeing a bright future for the European entrepreneurship research.

\section{REFERENCES}

Aaltonen, S. and U. Hytti (2015), 'Practices hindering employee innovative behaviour in manufacturing SMEs', in R. Blackburn, U. Hytti and F. Welter (eds), Context, Process and Gender in Entrepreneurship: Frontiers in European Entrepreneurship Research, Cheltenham, UK: Edward Elgar Publishing, pp.153-72.

Aggestam, M. (2014), 'Social entrepreneuring: the case of Swedish philanthrocapitalism', in R. Blackburn, F. Delmar, A. Fayolleand F. Welter(eds) Entrepreneurship, People and Organisations: Frontiers in European Entrepreneurship Research, Cheltenham, UK: Edward Elgar Publishing, pp.7-26.

Alsos, G.A., S. Carter and E. Ljunggren (2014), 'Entrepreneurial families and households', in T. Baker and F. Welter, Routledge Companion to Entrepreneurship, Routledge Companions in Business, Management and Accounting, Abingdon: Routledge, pp.165-78.

Alvesson, M. and A. Spicer (2012), 'Critical leadership studies: the case for critical performativity’, Human Relations, 65 (3), 367-90.

Ardichvili, A., R. Cardozo and S. Ray (2003), 'A theory of entrepreneurial opportunity identification and development', Journal of Business Venturing, 18 (1), 105-23.

Belousova, O. and B. Gailly (2012), 'Promoting corporate entrepreneurship within a large company: an in-depth case study', in F. Welter, D. Smallbone and A. Van Gils (eds), Entrepreneurial Processes in a Changing Economy: Frontiers in European Entrepreneurship Research, Cheltenham, UK: Edward Elgar Publishing, pp.159-76.

Bertoni, F., A. Croce and M. Guerini (2013), 'The effectiveness of public venture capital in supporting the investments of European young high-tech companies', in F. Welter, R. Blackburn, E. Ljunggren and B. Willy (eds), Entrepreneurial Business and Society: Frontiers in European Entrepreneurship Research, Cheltenham, UK: Edward Elgar Publishing, pp.79-100.

Bianchi, M., D. Chiaroni, F. Frattini and T. Minola (2013), 'A dynamic capability view on the determinants of superior performance in university technology transfer offices', in F. Welter, R. Blackburn, E. Ljunggren and B. Willy (eds), Entrepreneurial Business and Society: Frontiers in European Entrepreneurship Research, Cheltenham, UK: Edward Elgar Publishing, pp.101-23.

Billström, A., D. Politis and J. Gabrielsson (2014), 'Entrepreneurial networks in university spin-offs - an analysis of the external entrepreneur model', in R. 
Blackburn, F. Delmar, A. Fayolle and F. Welter (eds), Entrepreneurship, People and Organisations: Frontiers in European Entrepreneurship Research, Cheltenham, UK: Edward Elgar Publishing, pp.136-54.

Blackburn, R.A. and D. Smallbone (2008), 'Researching small firms and entrepreneurship in the UK: developments and distinctiveness', Entrepreneurship Theory and Practice, 32 (2), 267-88.

Blackburn, R., F. Delmar, A. Fayolle and F. Welter (eds), (2014), Entrepreneurship, People and Organisations: Frontiers in European Entrepreneurship Research, Cheltenham, UK: Edward Elgar Publishing.

Blackburn, R., U. Hytti and F. Welter (2015a), 'Introduction: entrepreneurship, contextual, process and gender differentiations', in R. Blackburn, U. Hytti and F. Welter (eds), Context, Process and Gender in Entrepreneurship, Frontiers in European Entrepreneurship Research, Cheltenham, UK: Edward Elgar Publishing, pp.1-5.

Blackburn, R., U. Hytti and F. Welter (eds), (2015b), Context, Process and Gender in Entrepreneurship: Frontiers in European Entrepreneurship Research, Cheltenham, UK: Edward Elgar Publishing.

Bosma, N., E. Stam and S. Wennekers (2014), 'Intrapreneurship versus entrepreneurship in high and low income countries', in R. Blackburn, F. Delmar, A. Fayolle and F. Welter (eds), Entrepreneurship, People and Organisations: Frontiers in European Entrepreneurship Research, Cheltenham, UK: Edward Elgar Publishing, pp.94-115.

Brand, M., E. Croonen and R. Leenders (2012), 'Knowledge acquisition through strategic networks: the case of franchising', in F. Welter, D. Smallbone and A. Van Gils (eds), Entrepreneurial Processes in a Changing Economy: Frontiers in European Entrepreneurship Research, Cheltenham, UK: Edward Elgar Publishing, pp.110-38.

Bull, I. and G.E. Willard (1993), 'Towards a theory of entrepreneurship', Journal of Business Venturing, 8 (3), 183-95.

Byrne, J. and S. Fattoum (2015), 'The gendered nature of family business succession: case studies from France', in R. Blackburn, U. Hytti and F. Welter (eds), Context, Process and Gender in Entrepreneurship: Frontiers in European Entrepreneurship Research, Cheltenham, UK: Edward Elgar Publishing, pp.127-52.

Campos, A. and E. Hormiga (2012), 'The state of the art of knowledge research in entrepreneurship: a ten-year literature review', in F. Welter, D. Smallbone and A. Van Gils (eds), Entrepreneurial Processes in a Changing Economy: Frontiers in European Entrepreneurship Research, Cheltenham, UK: Edward Elgar Publishing, pp.177-208.

Courault, J., M. Perez and C. Teyssier (2014), 'The failure of hyper-growth firms: a study of the bankruptcy of French SMEs with high growth potential', in R. Blackburn, F. Delmar, A. Fayolle and F. Welter (eds), (2014), Entrepreneurship, People and Organisations: Frontiers in European Entrepreneurship Research, Cheltenham, UK: Edward Elgar Publishing, pp.155-74.

Fayolle, A. (ed.), (2007), Handbook of Research in Entrepreneurship Education: A General Perspective, vol. 1, Cheltenham, UK, Edward Elgar Publishing.

Fayolle, A., B. Gailly and N. Lassas-Clerc (2006), 'Assessing the impact of entrepreneurship education programmes: a new methodology', Journal of European Industrial Training, 30 (9), 701-20.

Fayolle, A.P. and Kyrö (eds), (2008), The Dynamics Between Entrepreneurship, Environment and Education, Cheltenham, UK: Edward Elgar Publishing. 
Gabrielsson, J., D. Politis and A. Lindholm Dahlstrand (2014), 'Entrepreneurship and technological innovation: the influence of uncertainty and entrepreneurial ability on innovation speed in new technology start-ups', in R. Blackburn, F. Delmar, A. Fayolle and F. Welter (eds), Entrepreneurship, People and Organisations: Frontiers in European Entrepreneurship Research, Cheltenham, UK: Edward Elgar Publishing, pp.116-35.

García-Villaverde, P.M., M.J. Ruiz-Ortega and G. Parra-Requena (2012), 'New moderating factors for the pioneer's success', in F. Welter, D. Smallbone and A. Van Gils (eds), Entrepreneurial Processes in a Changing Economy: Frontiers in European Entrepreneurship Research, Cheltenham, UK: Edward Elgar Publishing, pp.68-87.

Gibb, A. (2002), 'In pursuit of a new "enterprise” and "entrepreneurship" paradigm for learning: creative destruction, new values, new ways of doing things and new combinations of knowledge', International Journal of Management Reviews, $4(3), 233-69$.

Gibb, A.A. (1993), 'Enterprise culture and education understanding enterprise education and its links with small business, entrepreneurship and wider educational goals', International Small Business Journal, 11 (3), 11-34.

Gioia, D.A., K.G. Corley and A.L. Hamilton (2012), 'Seeking qualitative rigor in inductive research: notes on the Gioia methodology', Organizational Research Methods, 16 (1), 15-31.

Göğüş, C.I., O. Orge and O. Duygulu (2015), 'Gendering entrepreneurship: a discursive analysis of a woman entrepreneur competition', in R. Blackburn, U. Hytti and F. Welter (eds), Context, Process and Gender in Entrepreneurship: Frontiers in European Entrepreneurship Research, Cheltenham, UK: Edward Elgar Publishing, pp.111-26.

Grande, J. (2013), 'Critical resources and capabilities for successful entrepreneurship: the case of agriculture', in F. Welter, R. Blackburn, E. Ljunggren and B. Willy (eds), Entrepreneurial Business and Society: Frontiers in European Entrepreneurship Research, Cheltenham, UK: Edward Elgar Publishing, pp.170-93.

Guerrero, M. and I. Peña-Legazkue (2014), 'The effect of human capital on firm creation: evidence from Spain', in R. Blackburn, F. Delmar, A. Fayolle and F. Welter (eds), Entrepreneurship, People and Organisations: Frontiers in European Entrepreneurship Research, Cheltenham, UK: Edward Elgar Publishing, pp. $27-50$.

Guerrero, M. and D. Urbano (2015), 'The effect of university and social environments on graduates' start-up intentions: an exploratory study in Iberoamerica', in R. Blackburn, U. Hytti and F. Welter (eds), Context, Process and Gender in Entrepreneurship: Frontiers in European Entrepreneurship Research, Cheltenham, UK: Edward Elgar Publishing, pp.55-86.

Heinonen, J., U. Hytti and E. Vuorinen (2013), 'Intrapreneurial risk-taking in public healthcare: challenging existing boundaries', in F. Welter, R. Blackburn, E. Ljunggren and B. Willy (eds), Entrepreneurial Business and Society: Frontiers in European Entrepreneurship Research, Cheltenham, UK: Edward Elgar Publishing, pp.149-69.

Hermes, J. and T. Mainela (2015), 'Institutional entrepreneuring in erratic environments', in R. Blackburn, U. Hytti and F. Welter (eds), Context, Process and Gender in Entrepreneurship, Frontiers in European Entrepreneurship Research, Cheltenham, UK: Edward Elgar Publishing, pp.34-54. 
Hjorth, D. (2008), 'Nordic entrepreneurship research', Entrepreneurship Theory and Practice, 32 (2), 313-38.

Horner, S. and B. Giordano (2016), "Made in Liverpool": exploring the contribution of a university-industry research partnership to innovation and entrepreneurship', in U. Hytti, R. Blackburn, D. Fletcher and F. Welter (eds), Entrepreneurship, Universities \& Resources: Frontiers in European Entrepreneurship Research, Cheltenham, UK: Edward Elgar Publishing, pp.168-94.

Hurmerinta, L. and E. Paavilainen-Mäntymäki (2013), 'Grasping the entrepreneurial opportunity process with diaries', in F. Welter, R. Blackburn, E. Ljunggren and B. Willy (eds), Entrepreneurial Business and Society: Frontiers in European Entrepreneurship Research, Cheltenham, UK: Edward Elgar Publishing, pp.194-212.

Huynh, T. (2016), 'Entrepreneurship and equity crowdfunding: a research agenda', in U. Hytti, R. Blackburn, D. Fletcher and F. Welter (eds), Entrepreneurship, Universities \& Resources, Frontiers in European Entrepreneurship Research, Cheltenham, UK: Edward Elgar Publishing, pp.30-48.

Hytti, U., R. Blackburn, D. Fletcher and F. Welter (eds), (2016), Entrepreneurship, Universities \& Resources, Frontiers in European Entrepreneurship Research, Cheltenham, UK: Edward Elgar Publishing.

Hytti, U. and C. O'Gorman (2004), 'What is "enterprise education"? An analysis of the objectives and methods of enterprise education programmes in four European countries, Education + Training, 46 (1), 11-23.

Johannisson, B., J. Alpenberg and P. Strandberg (2016), 'Exploring processes and structures in social entrepreneuring.: a practice-theory approach', in U. Hytti, R. Blackburn, D. Fletcher and F. Welter (eds), Entrepreneurship, Universities \& Resources, Frontiers in European Entrepreneurship Research, Cheltenham, UK: Edward Elgar Publishing, pp.6-29.

Karhunen, P. and I. Olimpieva (2016), 'Evolution of the scientrepreneur? Role identity construction of science-based entrepreneurs in Finland and in Russia', in U. Hytti, R. Blackburn, D. Fletcher and F. Welter (eds), Entrepreneurship, Universities \& Resources, Frontiers in European Entrepreneurship Research, Cheltenham, UK: Edward Elgar Publishing, pp.117-45.

Kitching, J., E. Kašperová and J. Collis (2013), 'The bearable lightness of the administrative burden - UK financial reporting regulation and small company performance', in F. Welter, R. Blackburn, E. Ljunggren and B. Willy (eds), Entrepreneurial Business and Society: Frontiers in European Entrepreneurship Research, Cheltenham, UK: Edward Elgar Publishing, pp.55-78.

Kyrö, P. (2015), 'The conceptual contribution of education to research on entrepreneurship education', Entrepreneurship \& Regional Development, 27 (9-10), 599-618.

Laveren, E., D. Helleboogh and N. Lybaert (2012), 'The use of financial bootstrapping in small and medium-sized ventures and the impact on venture growth', in F. Welter, D. Smallbone and A. Van Gils (eds), Entrepreneurial Processes in a Changing Economy: Frontiers in European Entrepreneurship Research, Cheltenham, UK: Edward Elgar Publishing Limited, pp.88-109.

Léger-Jarniou, C. and S. Tegtmeier (2017), 'Introduction: reopening the debate - a Delphi panel of the leading scholars in research on entrepreneurial opportunities', in C. Léger-Jarniou and S. Tegtmeier (eds), Research Handbook on Entrepreneurial Opportunities: Reopening the Debate, Cheltenham, UK: Edward Elgar Publishing, pp.1-44. 
Lumpkin, G.T. and G.G. Dess (1996), 'Clarifying the entrepreneurial orientation construct and linking it to performance', Academy of Management Review, 21 (1), 135-72.

Lumpkin, G.T. and G.G. Dess (2001), 'Linking two dimensions of entrepreneurial orientation to firm performance: the moderating role of environment and industry life cycle', Journal of Business Venturing, 16 (5), 429-51.

Marlow, S. (2015) Women, Gender and Entrepreneurship: Why Can't a Woman be More Like a Man?, in R. Blackburn, U. Hytti and F. Welter (eds), Context, Process and Gender in Entrepreneurship: Frontiers in European Entrepreneurship Research, Cheltenham, UK: Edward Elgar Publishing, pp.23-33.

Mauer, R., P. Eckerle and M. Brettel (2013), 'Adding missing parts to the intention puzzle in entrepreneurship education: entrepreneurial self-efficacy, its antecedents and their direct and mediated effects', in F. Welter, R. Blackburn, E. Ljunggren and B. Willy (eds), Entrepreneurial Business and Society: Frontiers in European Entrepreneurship Research, Cheltenham, UK: Edward Elgar Publishing, pp.127-48.

Nevalainen, O.M. and P. Eriksson (2016), 'How business angels found a way to contribute non-financially: a processual approach', in U. Hytti, R. Blackburn, D. Fletcher and F. Welter (eds), Entrepreneurship, Universities \& Resources, Frontiers in European Entrepreneurship Research, Cheltenham, UK: Edward Elgar Publishing, pp.49-69.

Ogbor, J.O. (2000), 'Mythicizing and reification in entrepreneurial discourse: ideology-critique of entrepreneurial studies', Journal of Management Studies, 37 (5), pp.605-35.

O'Gorman, C. (2012), 'The role of the entrepreneur in determining growth: a longitudinal analysis of a new venture', in F. Welter, D. Smallbone and A. Van Gils (eds), Entrepreneurial Processes in a Changing Economy: Frontiers in European Entrepreneurship Research, Cheltenham, UK: Edward Elgar Publishing, pp.47-67.

Örge, O. (2013), 'Entrepreneurship policy as discourse: appropriation of entrepreneurial agency', in F. Welter, R. Blackburn, E. Ljunggren and B. Willy (eds), Entrepreneurial Business and Society: Frontiers in European Entrepreneurship Research, Cheltenham, UK: Edward Elgar Publishing, pp.37-57.

Pittaway, L. and J. Cope (2007), 'Entrepreneurship education: a systematic review of the evidence', International Small Business Journal, 25 (5), 479-510.

Randerson, K., C. Bettinelli and A. Fayolle (2014), 'A configurational approach to entrepreneurial orientation', in R. Blackburn, F. Delmar, A. Fayolle and F. Welter (eds), Entrepreneurship, People and Organisations: Frontiers in European Entrepreneurship Research, Cheltenham, UK: Edward Elgar Publishing, pp.51-73.

Rasmussen, E. and T.H. Clausen (2012), 'Openness and innovativeness within science-based entrepreneurial firms', in F. Welter, D. Smallbone and A. Van Gils (eds), Entrepreneurial Processes in a Changing Economy: Frontiers in European Entrepreneurship Research, Cheltenham, UK: Edward Elgar Publishing, pp.139-58.

Ripsas, S. (1998), 'Towards an interdisciplinary theory of entrepreneurship', Small Business Economics, 10 (2), 103-15.

Salamonsen, K. (2016), 'Overcoming the smallness challenge in asymmetrical alliances', in U. Hytti, R. Blackburn, D. Fletcher and F. Welter (eds), Entrepreneurship, Universities \& Resources, Frontiers in European Entrepreneurship Research, Cheltenham, UK: Edward Elgar Publishing, pp.94-116. 
Schlosser, F. (2014), 'Differences in key employees by firm age and entrepreneurial orientation', in R. Blackburn, F. Delmar, A. Fayolle and F. Welter (eds), Entrepreneurship, People and Organisations: Frontiers in European Entrepreneurship Research, Cheltenham, UK: Edward Elgar Publishing, pp.74-93.

Schmude, J., F. Welter and S. Heumann (2008), 'Entrepreneurship research in Germany', Entrepreneurship Theory and Practice, 32 (2), 289-311.

Shaw, E., Wilson, J. and Pret, T. (2017), 'The process of embedding a small firm in its industrial context', International Small Business Journal, 35 (3), 219-43.

Sleutjes, B., F. Van Oort and V. Schutjens (2012), 'Cohesion, liveability and firm success in Dutch neighbourhoods', in F. Welter, D. Smallbone and A. Van Gils (eds), Entrepreneurial Processes in a Changing Economy: Frontiers in European Entrepreneurship Research, Cheltenham, UK: Edward Elgar Publishing, pp. $24-46$.

Tegtmeier, S. and J. Mitra (2015), 'Determinants and measurement of entrepreneurial self-efficacy among women entrepreneurs: empirical evidence from Germany', in R. Blackburn, U. Hytti and F. Welter (eds), Context, Process and Gender in Entrepreneurship: Frontiers in European Entrepreneurship Research, Cheltenham, UK: Edward Elgar Publishing, pp.87-110.

Varamäki, E., S. Joensuu-Salo and A. Viljamaa (2016), 'The intention-behaviour link of higher education graduates', in U. Hytti, R. Blackburn, D. Fletcher and F. Welter (eds), Entrepreneurship, Universities \& Resources, Frontiers in European Entrepreneurship Research, Cheltenham, UK: Edward Elgar Publishing, pp.146-67.

Welter, F. (2011), 'Contextualizing entrepreneurship - conceptual challenges and ways forward', Entrepreneurship Theory and Practice, 35 (1), 165-84.

Welter, F., R. Blackburn, E. Ljunggren and B. Willy (eds), (2013), Entrepreneurial Business and Society: Frontiers in European Entrepreneurship Research, Cheltenham, UK: Edward Elgar Publishing.

Welter, F., W.B. Gartner and M. Wright (2016), 'The context of contextualizing contexts', in F. Welter, W.B. Gartner and M. Wright (eds), A Research Agenda for Entrepreneurship and Context, Cheltenham, UK: Edward Elgar Publishing, pp.1-15.

Welter, F. and F. Lasch (2008), 'Entrepreneurship research in Europe: taking stock and looking forward', Entrepreneurship Theory and Practice, 32 (2), 241-8.

Welter, F., D. Smallbone and A. Van Gils (eds), (2012), Entrepreneurial Processes in a Changing Economy: Frontiers in European Entrepreneurship Research, Cheltenham, UK: Edward Elgar Publishing.

Wiklund, J. and D. Shepherd (2005), 'Entrepreneurial orientation and small business performance: a configurational approach', Journal of Business Venturing, 20 (1), 71-91.

Wright, M. (2012), 'Entrepreneurial mobility, resource orchestration and context', in F. Welter, D. Smallbone and A. Van Gils (eds), Entrepreneurial Processes in a Changing Economy: Frontiers in European Entrepreneurship Research, Cheltenham, UK: Edward Elgar Publishing Limited, pp.6-23.

Yavuz, R.S., H. Sapienza and Y. Chu (2016), 'Resource flexibility, early internationalization and performance', in U. Hytti, R. Blackburn, D. Fletcher and F. Welter (eds), Entrepreneurship, Universities \& Resources, Frontiers in European Entrepreneurship Research, Cheltenham, UK: Edward Elgar Publishing, pp.70-93. 
Zahra, S.A., R.K. Pati and L. Zhao (2013), 'How does counterproductive entrepreneurship undermine social wealth creation?', in F. Welter, R. Blackburn, E. Ljunggren and B. Willy (eds), Entrepreneurial Business and Society: Frontiers in European Entrepreneurship Research, Cheltenham, UK: Edward Elgar Publishing, pp.11-36. 